\title{
БИОЛОГИЯ
}

\section{Ботаника. Почвоведение}

УДК 582.542

DOI $10.18101 / 2587-7148-2019-2-5-14$

\section{СИСТЕМАТИЧЕСКОЕ ПОЛОЖЕНИЕ РАРАVЕR РОРОVII SIPL. СРЕДИ МАКОВ БАЙКАЛЬСКОЙ СИБИРИ НА ОСНОВЕ МОЛЕКУЛЯРНО-ГЕНЕТИЧЕСКИХ ИССЛЕДОВАНИЙ}

\section{Н. К. Бадмаева, Н. Б. Ешисамбуева, Е. В. Бухарова, Б-Ц. Б. Намзалов}

(C) Бадмаева Наталья Карловна

кандидат биологических наук,

Институт общей и экспериментальной биологии СО РАН

670047 , г. Улан-Удэ, ул. Сахьянова, 6

E-mail: badmayevan@mail.ru

\section{() Ешисамбуева Наталья Баторовна}

«Бурятский государственный университет имени Доржи Банзарова»

670000, Улан-Удэ ул. Смолина, д. 24а

E-mail: Darieshisambueva@yandex.ru

(C) Бухарова Евгения Васильевна

Кандидат биологических наук, «Заповедное Подлеморье»

670045, Улан-Удэ, ул. Комсомольская, 44-64

E-mail: darakna@mail.ru

\section{(C) Намзалов Бимба-Цырен Батомункуевич}

Доктор биологических наук, профессор

«Бурятский государственный университет имени Доржи Банзарова»

670000, Улан-Удэ ул. Смолина, д. 24а

E-mail: namzalov@rambler.ru

В работе приведены сведения по межвидовым отношениям 8 характерных таксонов рода Papaver L. Забайкалья и Прибайкалья, Восточного Саян. Проведено молекулярногенетическое исследование маков региона и их отношение эндемику побережья оз. Байкал Papaver popovii Sipl. В результате сравнительного анализа получены данные о родстве маков Байкальской Сибири. Выявлены связи родства между видами P. rubro-aurantiacum, P. pseudocanenscens и P. setosum, объединяющиеся в одну кладу. С другой стороны анализ образцов из различных забайкальских популяций одного вида $P$. nudicaule показали их неоднородность и при этом они также имели некоторые морфологические отличия. Результаты исследований подтвердили самостоятельность эндемичного таксона Papaver popovii Sipl. Однако генетический анализ обнаружил близость ее с другим эндемичным видом западного побережья Байкала - P. olchonense. Следует также отметить, что анализ древа подтвердил самостоятельность таких видов 
как P. croceum и P. czekanowskii. Заслуживает внимания позиция P. rubro-aurantiacum, формирующая субкладу из родства $P$. setosum - P. pseudocanenscens.

Ключевые слова: род Papaver, ISSR-анализ, ITS1-5.8S-ITS2, филогенетическое дерево.

\section{Для цитирования:}

Бадмаева Н. К., Еиисамбуева Н. Б., Бухарова Е. В., Намзалов Б-Ц. Б. Систематическое положение Papaver popovii Sipl. среди маков Байкальской Сибири на основе молекулярно-генетических исследований // Вестник Бурятского государственного университета. Биология, география. 2019. № 2. С. 5-14.

Вид Papaver popovii Sipl. впервые описан В.Н. Сипливинским по его собственным сборам 8.09.1971 г. с острова Мохнатый Калтыгей в Чивыркуйском заливе оз. Байкал (Сипливинский, 1973). Изотип хранится в гербарии П.Н. Крылова (ТК), дубликат хранится в гербарии LE, Ботанического института (Гуреева, Балашова, 2017).

P. popovii - узколокальный эндемик побережий оз. Байкал, является ледниковым реликтом (Попов, Бусик, 1966) и краснокнижным редким охраняемым видом. В Бурятии отмечен в Баргузинском районе в Чивыркуйском заливе на островах Лохматый и Голый Кылтыгей. Вне Бурятии в Иркутской области обнаружен в нескольких пунктах Ольхонского района: мысы Уюга, Зундук, Шартлай, Рытый и на острове Ольхон - мыс Хобой и Саган-Хушун (Красная книга Республики Бурятия ..., 2002; Красная книга Иркутской ..., 2010; Красная книга Республики Бурятия $\ldots, 2013)$.

На острове Лохматый Кылтыгей отмечена популяция $P$. popovii площадью около 400 кв. м. Структура популяции полночленная, отмечается семенное возобновление. Плотность ценопопуляций - до 3 особей на 1 кв. м. Лимитирующими факторами, возможно, являются экзогенные факторы, такие как, эрозия каменисто-щебнистых склонов, усиление рекреационной нагрузки на местообитания.

Вид охраняется в пределах Забайкальского национального парка (Аненхонов, Пыхалова, 2010). Вне Бурятии большинство известных в Иркутской области популяций взяты под охрану в Байкало-Ленском заповеднике, Прибайкальском природном национальном парке и комплексном памятнике природы областного значения «Мыс Хобой» (Красная книга Иркутской ..., 2010).

P. popovii многолетнее травянистое рыхлодерновинное растение (рис. 1). Листья на длинных тонких черешках, разреженно беловолосистые, пластинки в 2-2,5 раза короче черешков, яйцевидные, дважды перисторассеченные, доли листьев продолговатые или яйцевидные, глубоко, почти до основания, надрезанные на линейно-ланцетные дольки. Цветоносы 12-45 см высотой, прижато опушенные светлыми волосками. Чашелистики густо опушены темно-бурыми или рыжеватыми волосками. Цветки 3-6 см диаметром, чаще белые, реже серно-желтые. Коробочки 1,0-1,5 см длиной, продолговато-обратнояйцевидные, с рассеянными светлыми или слегка рыжеватыми щетинками, иногда почти голые (Флора Сибири, 1994). 
Бадмаева Н. К., Еиисамбуева Н. Б., Бухарова Е. В., Намзалов Б-Ц. Б. Систематическое положение Papaver popovii Sipl. среди маков Байкальской Сибири на основе...

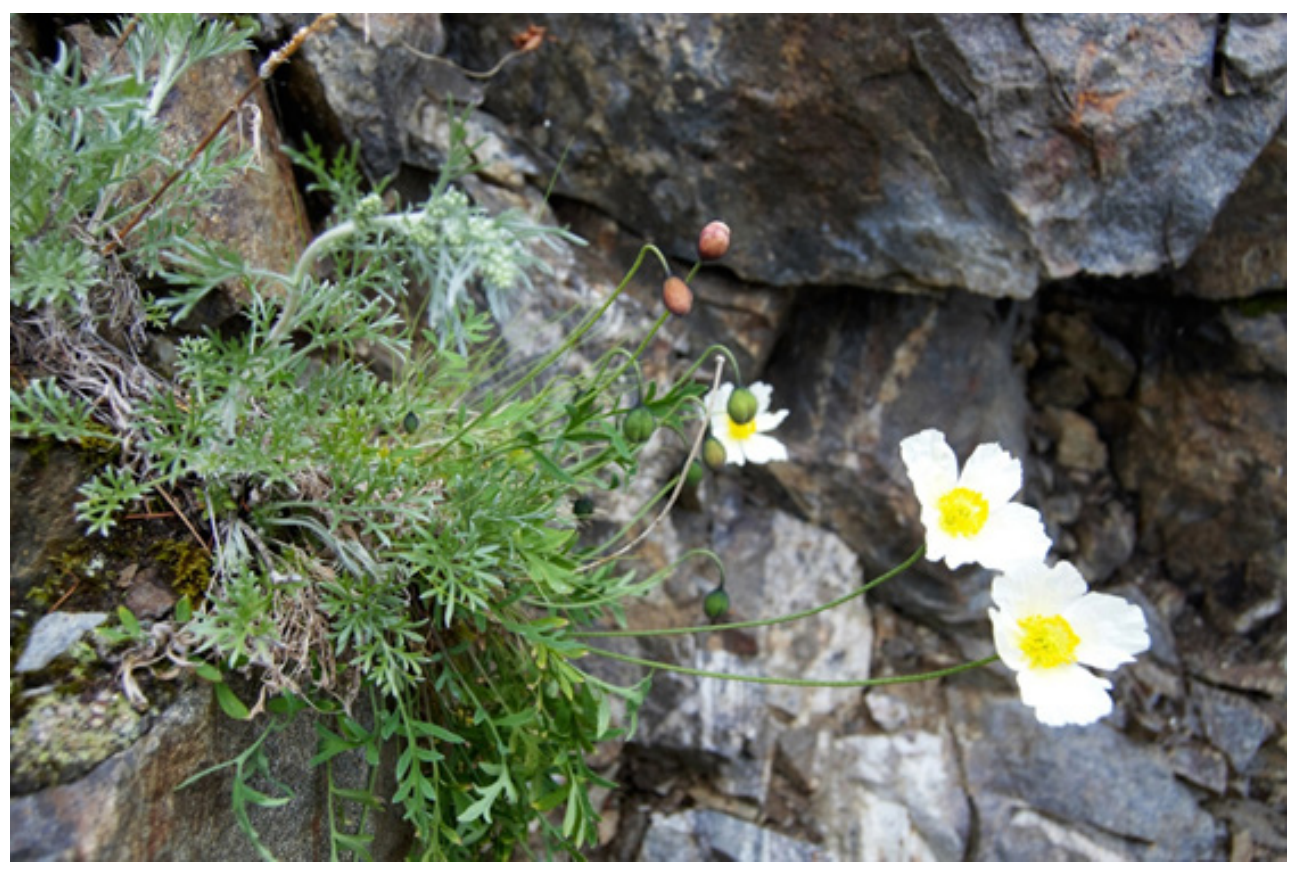

Рис. 1. Papaver popovii Sipl. Чивыркуйский залив, остров Лохматый. Мак Попова на крутых каменистых склонах с группировками Draba hirta L., Cortusa sibirica Andrz. и других. (Фото Е. В. Бухаровой)

В систематике рода Papaver L. много вопросов, связанных с таксономией. Некоторые морфологические признаки сильно варьируют в зависимости от экологических условий. Хотя количество видов, произрастающих на территории Байкальской Сибири невелико, высок процент эндемиков от общего числа видов (Флора Сибири, 1994; Малышев, Пешкова, 1984).

Во «Флоре СССР» (1937) род обработан М. Г. Поповым и число таксонов составляет 52, из них 8 видов отмечалось в Восточной Сибири. С К. Черепанов (1995) указывает 99 таксонов рода Papaver для России и сопредельных государств, из них 26 таксонов приводятся для Восточной Сибири. Во «Флоре Сибири» (1994) в обработке Г. А. Пешковой род представлен 32 таксонами. По «Определителю растений Бурятии» (2001) в обработке К. И. Осипова 12 видов встречаются в Западном Забайкалье. По «Конспекту Флоры Азиатской России» (2012) 18 таксонов указаны для Байкальской Сибири.

Материалы и методы.

ДНК выделен из 11 гербарных образцов 8 таксонов (Таблица 1.). Ваучерные гербарные образцы хранятся в гербарии UUH.

Молекулярно-генетические исследования проводились по общепринятым протоколам с индивидуальным подбором праймеров и условий амплификации.

Тотальную ДНК выделяли из 20 мг высушенных в силикагеле образцов с использованием кита «NucleoSpin Plant II Kit» (Macherey-Nagel, Германия) по стандартному протоколу производителя. Полимеразную цепную реакцию (ПЦР) осуществляли в термоциклере BIO-RAD T100 ${ }^{\mathrm{TM}}$ (BIO-RAD, США). 
Список образцов для молекулярно-генетического исследования

\begin{tabular}{|c|c|c|}
\hline № & Виды & Происхождение образца (ваучер) \\
\hline 1 & P. nudicaule $L$. & $\begin{array}{l}\text { Гербарий высших растений Иркутского госуниверситета } \\
\text { РБ. Кяхтинский р-н, } 3,8 \text { км ЮВ с. Мурочи грядовые пески. } \\
\text { Н. А. Дулепова }\end{array}$ \\
\hline 2 & P. nudicaule $L$. & $\begin{array}{l}\text { Гербарий высших растений Иркутского госуниверситета. } \\
\text { РБ. Селенгинский р-н, у парома через р. Чикой, в районе } \\
\text { впадения его в Селенгу. } 12.06 .2006 \text { г. Соб.: И. Евтушенко, } \\
\text { Е. Ведерникова. Опр.: Н. А. Дулепова }\end{array}$ \\
\hline 3 & P. croceum & $\begin{array}{l}\text { ИОЭБ СО РАН Гербарий UUH . Восточный Саян, Китой- } \\
\text { ские Гольцы, левобережье Горлык-Гола, верх. ключа Зелено- } \\
\text { го. h-2300 м., альпийский луг. Соб.: Шумкин В. П. } 30 \text { июля } \\
\text { 2002г. }\end{array}$ \\
\hline 4 & P. popovii Sipl. & $\begin{array}{l}\text { ИОЭБ СО РАН Гербарий UUH. Баргузинский р-н, Чи- } \\
\text { выркуйский залив, о. Большой Калтыгей, N } 53^{\circ} 48.930 \text {, Е } \\
109^{\circ} 05.063 \text {, Крутой каменистый склон. Соб.: Бадмаева Н.К. } \\
\text { 5.07. 13. }\end{array}$ \\
\hline 5 & P. czekanovskii & $\begin{array}{l}\text { ИОЭБ СО РАН Гербарий UUH . Баунтовский район долина } \\
\text { реки Горбылок } \\
\text { Глинисто песчаный берег. Г. А. Пешкова, } 1991 .\end{array}$ \\
\hline 6 & P. nudicaule L. & $\begin{array}{l}\text { Гербарий высш. раст. Иркутского госуниверситета. РБ, Би- } \\
\text { чурский р-н, } 10 \text { км СВ от пос. Окино-Ключи, лев. берег р. } \\
\text { Хилок. Парковый ильмовник в пойме реки. 14.06.2006 } \\
\text { Собрал: В. Чепинога, А. Фролов; Определил: Н. А. Дулепо-- } \\
\text { ва. №16107 }\end{array}$ \\
\hline 7 & $\begin{array}{l}\text { P. olchonense } \\
\text { Peshkova }\end{array}$ & $\begin{array}{l}\text { Гербарий Сибирского института физиологии и биохимии } \\
\text { растений СО РАН (Ирк) } \\
\text { Иркутская область, Ольхонский р-н, поб-е оз. Байкал, мыс. } \\
\text { Уюга, Галечниковый перешеек. 4.09.2010 г. Соб.: Д. А. Кри- } \\
\text { венко, Е. С. Преловская. } 15.11 .2010 \text { г. Опр: С. Г. Казановский }\end{array}$ \\
\hline 8 & $\begin{array}{l}\text { P. rubro-aurantiacum } \\
\text { Ficher ex R.Sweet }\end{array}$ & $\begin{array}{l}\text { Гербарий UUH Института биологии БФ СО АН СССР. } \\
\text { РБ. Кабанский р-н, степь. } \\
\text { Соб.: Т. Г. Бойков }\end{array}$ \\
\hline 9 & $\begin{array}{l}\text { P. rubro- aurantiacum } \\
\text { Ficher ex R.Sweet }\end{array}$ & $\begin{array}{l}\text { ИОЭБ СО РАН Гербарий UUН. РБ Еравинский р-н. Долина } \\
\text { р.Зазы, в } 5 \text { км к сев.-востоку от устья р. Ехэ Горхон, } 982 \text { м. } \\
\text { N 53¹2/351” Е } 111^{\circ} 48.960 ” \text { З Злаково-разнотравная степь } \\
\text { Соб. и опр.: О. А. Аненхонов, } 2008\end{array}$ \\
\hline 10 & P. psedocanescene & $\begin{array}{l}\text { Гербарий UUH Института биологии БФ СО АН СССР. РБ. } \\
\text { Окинский р-н долина р. Китой, } 10 \text { км к зап. От устья р. Са- } \\
\text { тан-Сойр на песчаной осыпи. Соб. и опр.: О. А. Аненхонов } \\
24.08 .1992\end{array}$ \\
\hline 11 & P. setosum & $\begin{array}{l}\text { Гербарий UUH Института биологии БФ СО РАН СССР } \\
\text { РБ, хр. Улан-Бургасы, долина р. Мостовая, опушка леса. } \\
\text { Соб. и опр.: Т. Г. Бойков } 11.07 .1986\end{array}$ \\
\hline
\end{tabular}


Бадмаева Н. К., Еиисамбуева Н. Б., Бухарова Е. В., Намзалов Б-Ц. Б. Систематическое положение Papaver popovii Sipl. среди маков Байкальской Сибири на основе...

Амплификация ДНК для участка ITS1-5.8S-ITS2 рДНК проводилась в растворе объемом 20 мкл, содержащем 2 мкл 10x Tag-буфера; 2 мкл 25 мM MgCl (финальная концентрация - 2,5 mM); 2 мкл $10 \mathrm{mM}$ dNTPs (финальная концентрация - 0,2 мМ); 1 мкл DMSO (4\%); 1 мкл 10 пмоль прямого (F) и 1 мкл 10 пмоль обратного (R) праймеров; 8,7 мкл стерильной деионизированной воды $\left(\mathrm{dd} \mathrm{H}_{2} \mathrm{O}\right)$; 0,3 мкл Tag-полимеразы (5 ед/мкл); 2 мкл геномной ДНК (20-40 нг/мкл) (реактивы и праймеры фирмы «Синтол», Россия). Участок ITS1-5.8S-ITS2 рДНК амплифицировали с использованием праймеров: ITS1 (F), ITSB (R) и ITS2 (R) (табл. 3) в программе по A. Gardiner et all. (2005). ПЦР-продукты визуализировали в $1 \%$-ном агарозном геле с использованием SybrGreen (фирмы «BioDye» Москва, Россия) при 4 B/см. Амплификат очищали набором Mini Elute PCR Purification Kit (Qiagen, Германия). Концентрацию ДНК измеряли флюориметром Qubit (Invitrogen, США). Секвенирование ITS1-5.8S-ITS2 рДНК выполнялось по методу Сэнгера на базе «Синтол» (Москва). Последовательности выравнивали вручную в программе BioEdit Sequence Alignment Editor (Hall, 1999). Филогенетическое дерево на основе ITS1-5.8S-ITS2 региона построено в программе Winclada, с применением программы Nona.

Результаты и обсуждение

Для определения уровней межвидового полиморфизма, и определения взаимоотношений между видами и точного идентифицирования образцов, был использован метод, основанный на применении ISSR-анализа полиморфизма длин амплифицированных фрагментов с ISSR-праймерами. Для ISSR-анализа видов исследуемого рода был проведен предварительный поиск рабочих праймеров. Были протестированы 17 ISSR-праймеров. Длина праймеров составила от 11 п.н. до 18 п.н., температура отжига от 36 до $58,7^{\circ} \mathrm{C}$. Из них были выбраны пять праймеров, которые дали наибольшие количество ампликонов в пределах от 200 до 1500 пар нуклеотид: 17898A, 17898B, UBC-857, UBC-818, 835-В. В таблице 2 даны характеристики рабочих праймеров.

Таблица 2

Характеристика праймеров для амплификации ISSR

\begin{tabular}{|l|l|l|c|}
\hline Праймер* & \multicolumn{1}{|c|}{$\begin{array}{c}\text { Нуклеотидная } \\
\text { последовательность 5'-3, }\end{array}$} & \multicolumn{1}{|c|}{ Формула } & $\begin{array}{c}\text { Темп-ра } \\
\text { отжига, }{ }^{\mathbf{}} \mathbf{C}\end{array}$ \\
\hline 17898A & CACACACACACAAC & (CA)6AC & 42 \\
\hline 17898B & CACACACACACAGT & (CA)6GT & 42 \\
\hline UBC857B & ACACACACACACACACTG & (AC)8TG & 36 \\
\hline UBC818 & CACACACACACACACAG & (CA)G & 36 \\
\hline UBC835B & AGAGAGAGAGAGAGAGTT & (AG)8TT & 52 \\
\hline
\end{tabular}

*Праймеры синтезированы в компании «Евроген» (Москва). 


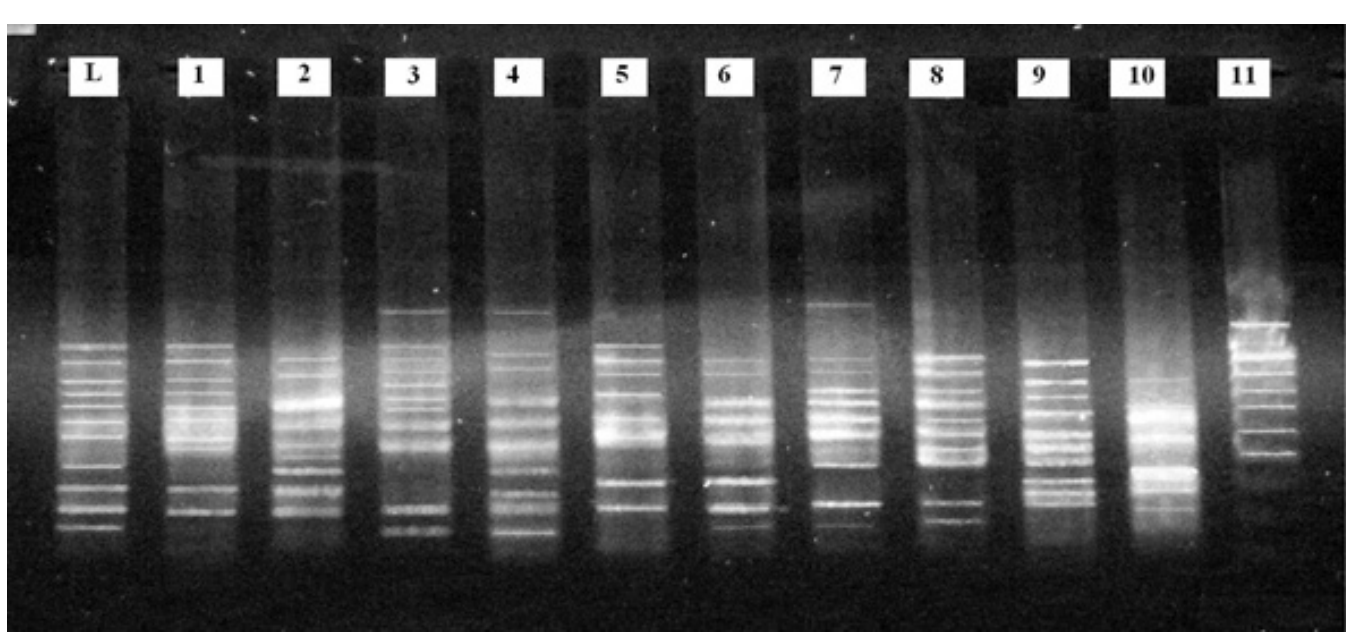

Рис. 2. Гель с праймера 835-B. L — мол. линейка. Номера образцов даны выше в тексте.

На рисунке 2. показана наиболее информативная гель-электрофорез с праймера 835-В. При обработке пяти гелей была составлена бинарная матрица, где отсутствие ампликона обозначали «0», присутствие «1». На основании полученной матрицы с пяти праймеров с использованием методов иерархического кластерного анализа (UPGMA) в программе «Статистика» и ближайщего связывания в программе TreeconW 3.2 определены генетические расстояния между видами и построены дендограммы, отражающие взаимоотношения анализируемых видов рода Papaver (рис. 3 и 4).

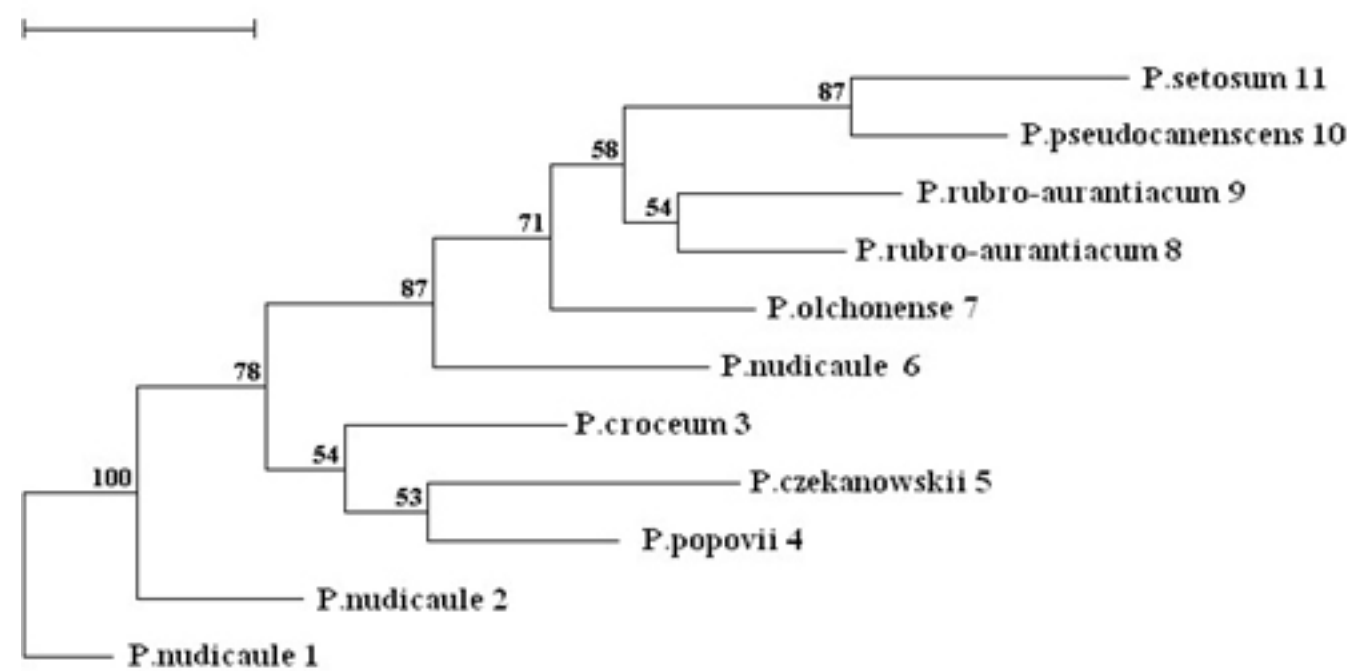

Рис. 3. ISSR-дендрограмма построенная при помощи кластерного анализа UPGMA, показывающее взаимоотношения 8 видов рода Papaver Западного Забайкалья. 
Бадмаева Н. К., Ешисамбуева Н. Б., Бухарова Е. В., Намзалов Б-Ц. Б. Систематическое положение Papaver popovii Sipl. среди маков Байкальской Сибири на основе...

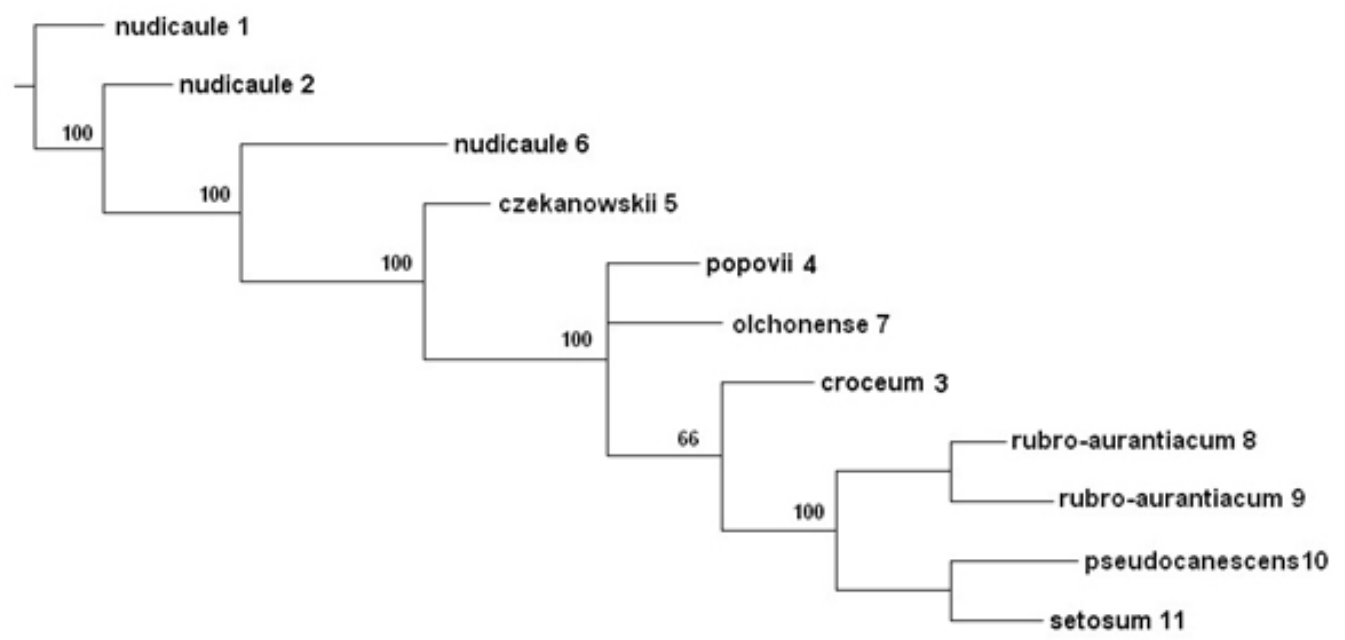

Рис. 4. ISSR-дендрограмма построенная по методу ближайшего связывания, показывающее взаимоотношения 8 видов рода Papaver Западного Забайкалья.

Oбе ISSR-дендрограммы дали более-менее одинаковые результаты. Так, например, на обеих дендрограммах P. pseudocanescens (обр.10) группируется в одном кластере с P. setosum (обр.11). И особенно выделяется P. olchonense (обр.7), он образует свой отдельный кластер. Нa UPGMA дендрограмме хорошо выделяется две большие клады, образцы видов P. nudicaule (обр.1) (Кяхтинский район), P. nudicaule (обр.2) (Селенгинский район), P. croceum (обр.3) (Восточный саян), P. popovii (обр.4) (Баргузинский район), P. czekanowskii (обр.5) (Баунтовский район), P. nudicaule (обр.6) (Бичурский район) вошли в первую кладу. А образцы видов P. rubro-aurantiacum (обр.8-9) (Еравинский район, Кабанский район), P.pseudocanescene (обр.10) (Окинский район), P. setosum (обр.11) (Хр. УланБургасы) составили вторую кладу, также вторая клада распадается еще на две маленькие субклады. Два образца вида P. rubro- aurantiacum (обр.8-9) из Кабанского и Еравнинского районов объединяются в одну субкладу. Образцы P.pseudocanescens (обр.10) из Окинского района и P. setosum (обр.11) с хр. Улан-Бургасы группируются в первую маленькую субкладу. P. popovii (обр.4) и P. czekanowskii (обр.5) объединяются в одну субкладу.

Следует указать, что филогенетическое дерево, построенное на основе ITS15.8S-ITS2 подтверждает данные, полученные на основе деревьев ISSR-гелей (рис. 5).

В целом, полученные нами результаты позволяют сделать некоторые выводы о родственных связях в изученной группе видов. Образцы вида P. rubro-aurantiacum из Кабанского и Еравнинского райнов и $P$. pseudocanenscens (Окинский район долина реки Китой), P. setosum (Хр. Улан-Бургасы, долина р. Мостовая) объединяются в одну кладу, что доказывает родственные отношения. 


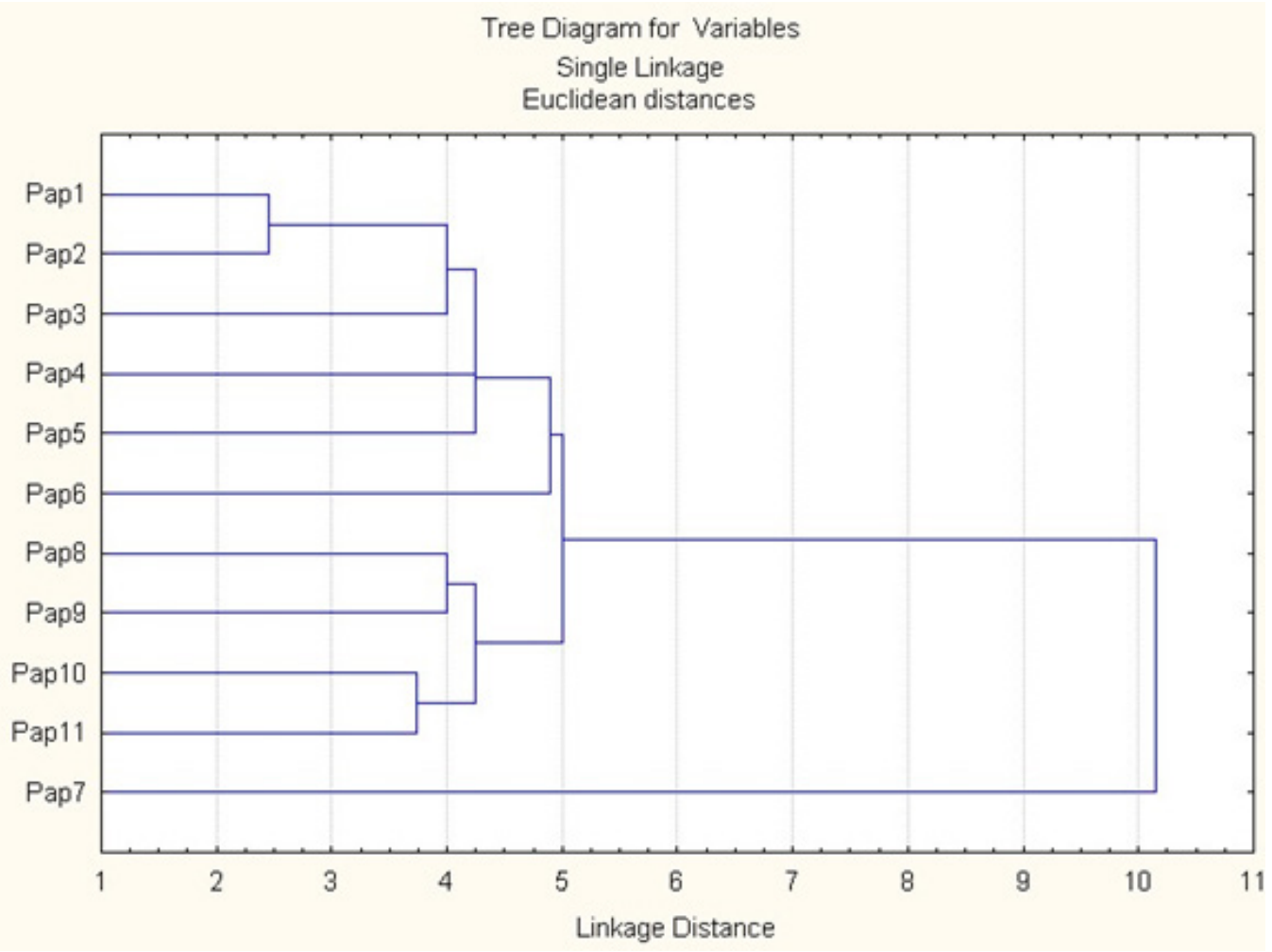

Рис. 5. Филогенетическое дерево, построенное на основе ITS1-5.8S-ITS2 региона, показывающее взаимоотношения изученных видов рода Papaver.

На основании полученного филогенетического дерева на основе последовательностей ITS1-5.8S-ITS2, можно утверждать, что $P$. popovii (Баргузинский район, Чивыркуйский залив, о. Большой Калтыгей), является эндемиком и самостоятельным таксоном, и в то же время близок с эндемиком P. olchonense (Иркутская область, Ольхонский район, маломорское побережье оз. Байкал, мыс. Уюга). Анализ дерева также подтвердил самостоятельность таких видов, как P. rubroaurantiacum, $P$. croceum, $P$. czekanowskii.

Образцы вида P. nudicaule 1 (Кяхтинский район), P. nudicaule 2 (Селенгинский район), P. nudicaule 6 (Бичурский район) на древе не объединились в одну кладу. ISSR- и ITS-анализы показали неоднородность 3-х образцов $P$. nudicaule из разных районов, морфологически эти образцы также сильно отличались. Нельзя сделать окончательные выводы и по таким видам, как P. pseudocanescens и P. setosum, которые группируются в одну кладу.

Благодарности. Сбор образиов проведен при поддержке проекта РФФИ № 18-45-030026; молекулярно-генетические исследования проведены при поддержке бюджетного проекта ИОЭБ СО РАН № АААА-А17-117011810036-3 и гранта БГУ № 19-10-0502 
Бадмаева Н. К., Ешисамбуева Н. Б., Бухарова Е. В., Намзалов Б-Ц. Б. Систематическое положение Papaver popovii Sipl. среди маков Байкальской Сибири на основе...

\title{
Литература
}

1. Аненхонов О. А., Пыхалова Т. Д. Конспект флоры сосудистых растений Забайкальского национального парка. Улан-Удэ: Изд-во БНЦ СО РАН, 2010. 228 с.

2. Гуреева И. И., Балашова В. Ф. Типовые образцы Papaveraceae Juss. в Гербарии им. П. Н. Крылова (ТК) // Систематические заметки. 2017. № 116. С. $29-37$.

3. Конспект Флоры Азиатской России: Сосудистые растения / Л. И. Малышев [и др.]; под ред. К. С. Байкова. Новосибирск: Изд-во СО РАН, 2012. 640 с.

4. Красная книга Иркутской области / Правительство Иркутской области. Министерство природных ресурсов и экологии Иркутской области. Ответственный редактор В. В. Попов. Иркутск: ООО Изд-во «Время странствий», 2010. 480 с.

5. Красная книга республики Бурятия: Редкие и исчезающие виды растений и грибов / Изд. 2-е перераб. и доп. Новосибирск: Наука, 2002. 340 с.

6. Красная книга Республики Бурятия: Редкие и находящиеся под угрозой исчезновения виды животных, растений и грибов / Изд. 3-е, перераб. и доп., отв. ред. Н. М. Пронин. Улан-Удэ: Изд-во БНЦ СО РАН, 2013. 688 с.

7. Малышев Л. И., Пешкова Г. А Особенности и генезис флоры Сибири (Предбайкалье и Забайкалье). Москва: Наука, 1984. 266 с.

8. Определитель растений Бурятии / под ред. О. А. Аненхонова. Улан-Удэ, 2001. $672 \mathrm{c}$.

9. Попов М. Г., Бусик В. В. Конспект флоры побережий озера Байкал. М.-Л.: Наука, 1966. $216 \mathrm{c}$.

10. Сипливинский В. Н. Заметки о байкальской флоре, 1 // Новости систематики высших растений. 1973. Т. 10. С. 345-361.

11. Флора Сибири. Новосибирск: Наука, 1994. Т. 7.312 с.

12. Флора СССР / под ред. В. Л. Комарова, Б. К. Шишкина. Москва; Ленинград: Издво Академии Наук СССР, 1937. Т. 7. 790 с.

13. Черепанов С. К. Сосудистые растения России и сопредельных государств (в пределах бывшего СССР). СПб.: Мир и семья, 1995. 992 с.

14. Gardiner, A., Ignatov M., Huttunen S. \& Troitsky A. On resurrection of the families Pseudoleskeaceae Schimp. and Pylaisiaceae Schimp. (Musci, Hypnales) // Taxon. 2005. Vol. 54. P. 651-663.

15. Hall T. A. BioEdit: a user-friendly biological sequence alignment editor and analysis program for Windows 95/98/ NT. // Nucl. Acids. Symp. 1999. Ser. 41. P. 95-98.

\section{THE SYSTEMATIC POSITION OF PAPAVER POPOVII SIPL. AMONG THE POPPIES OF BAIKAL SIBERIA BASED ON MOLECULAR GENETIC STUDIES}

\author{
N. K. Badmaeva, N. B. Eshisambueva, E. V. Bukharova, B. B. Namzalov \\ Badmaeva Natalya Karlovna \\ Cand. Sci. (Biol.), \\ Institute of General and Experimental Biology SD RAS, 8 Sahyanova st., Ulan-Ude, 670047 \\ E-mail: badmayevan@mail.ru
}

\section{Yeshisambueva Natalya Batorovna}

Banzarov Buryat State University, 24a Smolina st., Ulan-Ude, 670000

E-mail: Darieshisambueva@yandex.ru 


\section{Bukharova Evgenia Vasilyevna}

Cand. Sci. (Biol.),

Federal State Institution "Zapovednoe Podlemorye",

44-64 Komsomolskaya st., Ulan-Ude, 670045

E-mail: darakna@mail.ru

\section{Namzalov Bimba-Tsyren Batomunkuevich}

Doctor of Biological Sciences, professor

Banzarov Buryat State University, 24a Smolina st., Ulan-Ude, 670000

E-mail: namzalov@rambler.ru

The article presents information on interspecific relations of 8 characteristic taxa of the genus Papaver L. of Transbaikalia, Pribaikalye and Eastern Sayan. A molecular genetic study of poppies in the region and their relationship to the endemic of the coast of the lake Baikal Papaver popovii Sipl. Because of a comparative analysis, data on the relationship of poppies of the Baikal Siberia were obtained. Relationships between the species of P. rubroaurantiacum, $P$. pseudocanenscens and $P$. setosum, uniting into one clade, are revealed. On the other hand, the analysis of samples from different Transbaikalian populations of the same species of P. nudicaule showed their heterogeneity and, at the same time, they also had some morphological differences. The study results confirmed the independence of the endemic taxa Papaver popovii Sipl. However, genetic analysis revealed its proximity with another endemic species of the western coast of Lake Baikal - P. olchonense. It should also be noted that the analysis of the phylogenetic tree confirmed the independence of such species as $P$. croceum and $P$. czekanowskii. The position of $P$. rubro-aurantiacum, which forms the subclade from the relationship of $P$. setosum - P. pseudocanenscens, deserves attention.

Keywords: genus Papaver L, ISSR-analysis, ITS1-5.8S-ITS2, phylogenetic tree. 